\section{Efficacy of Four Irrigation Needles in Cleaning the Apical Third of Root Canals}

Juliane Maria Guerreiro-Tanomaru', Livia Etchebehere Loiola11', Renata Dornelles Morgental ${ }^{2}$, Renato de Toledo Leonardo ${ }^{1}$, Mario Tanomaru-Filho ${ }^{1}$

This study aimed to evaluate the influence of irrigation needle gauge and design, and the final root canal diameter on the apical cleaning efficacy. Twelve human mandibular incisors were used. At different stages of root canal widening (sizes 20, 30 and $40 \mathrm{~K}$-files), root canals were filled with radiopaque contrast medium. Four different needles were evaluated: $23 \mathrm{G}$ with side opening, $22 \mathrm{G}$ with apical opening, $30 \mathrm{G}$ with side opening and $30 \mathrm{G}$ with apical opening. Irrigation was carried out with $2 \mathrm{~mL}$ distilled water. The same tooth was radiographed with a digital system several times to assess the four types of needle in those three stages of canal widening. Pre-irrigation (canals filled with contrast) and post-irrigation (canals with remaining contrast) images were submitted to digital subtraction using the Adobe Photoshop CS4 program. Pre-irrigation (filled with contrast) and subtracted (cleaned by irrigation) areas were outlined by a trained and blinded operator using the Image Tool 3.0 software. Their ratio was calculated to express the percentage of apical cleaning in each stage of canal widening (sizes 20,30 and $40 \mathrm{~K}$-files) with each of the four needles. Data obtained were subjected to one-way ANOVA and Tukey's tests. The $30 \mathrm{G}$ needles with side and apical opening promoted better apical cleaning at all stages of root canal widening $(p<0.05)$. In conclusion, smaller diameter needles were more efficacious in cleaning the apical third of the root canals, regardless of their design.

\begin{abstract}
'Department of Restorative Dentistry, Araraquara Dental School, Univ Estadual Paulista UNESP, Araraquara, SP, Brazil ${ }^{2}$ Department of Endodontics, Dental School, Pontifical Catholic University of Rio Grande do Sul PUCRS, Porto Alegre, RS, Brazil
\end{abstract}

Correspondence: Mário Tanomaru Filho, Rua Humaitá, 1680, Caixa Postal 331, Centro, 14801-903 Araraquara, SP, Brasil. Tel. +55-16-3301-6390. e-mail: tanomaru@uol.com.br

\section{Introduction}

Root canal irrigation and instrumentation promote cleaning and disinfection of the root canal, contributing for the success of endodontic therapy (1). The ideal irrigation solution should remove debris, lubricate the root canal walls, dissolve organic tissues and eliminate bacteria. Regardless of the used irrigating solution, the endodontic microbiota is significantly reduced by the mechanical action of irrigation (2).

Efficacy of root canal irrigation depends on several factors, such as depth of needle insertion into the canal (3), final diameter of the prepared canal (4), canal curvature (5), as well as volume and properties of the used solution (6).

Greater approximation of the irrigating device to the contaminated area favors its effectiveness (3). Thus, penetration of the irrigating needle into the apical portion of the root canal is important for complete removal of debris and endodontic microorganisms $(7,8)$. Consequently, irrigation needle gauge and the amount of root canal widening may affect the cleaning efficacy. The widely used "gauge" unit is not directly comparable to the size of endodontic instruments. According to the ISO 9626 1991/2001 standard, needles with gauges of 21, 23, 25, 27 and 30 present external diameter of $0.8,0.6,0.5,0.4$ and $0.3 \mathrm{~mm}$, respectively (9).

Radiography has been employed to evaluate the cleaning efficacy of irrigation, by analyzing the clearance of radiopaque contrast medium from the root canals $(7,10)$.
Subtraction of images using conventional software is also an important evaluation tool (11). This method is used to evaluate irrigant penetration and renewal during root canal preparation (12). Moreover, digital radiography provides good image quality (13), with advantages of reducing radiation exposure, saving time and producing standardized images that can be manipulated with different tools (14).

The aim of this study was to evaluate, by means of digital radiography, the influence of the gauge and design of the irrigation needle and the size of root canal widening on the apical cleaning efficacy of endodontic irrigation.

\section{Material and Methods}

After approval of the research by the institutional Ethics Committee (Protocol\# 20/09), 12 freshly extracted human mandibular incisors with a single and straight root canal, fully formed root and initial diameter corresponding to a \#15 K-file or smaller were selected. Coronal access was performed with a \#1012 spherical diamond bur (KG Sorensen, São Paulo, SP, Brazil) and complemented with a \# 1 Largo drill (Dentsply Maillefer, Ballaigues, Switzerland). Following that, root canal length was determined by introducing a \#10 K-file (Dentsply Maillefer) until its tip was visible at the apical foramen. Working length was established by subtracting $1 \mathrm{~mm}$ from the total length.

The root canals were hand-instrumented and widened up to size 20,30 or $40 \mathrm{~K}$-files at the working length. Next, 
the root canals were filled with a radiopaque contrast medium (Pielograf 76\%; BerliMed SA, Madrid, Spain) thickened with propylene glycol (Arte \& Ciência Drugstore, Araraquara, SP, Brazil) and zinc oxide (Biodinâmica, lbiporã, $P R$, Brazil) at a 3:1:1 ratio (by mass). The apical foramina were sealed with red wax.

Irrigation needles of different gauges and designs were tested for each stage of root canal widening. The following needles were used: $23 \mathrm{G}$ with side opening (Optimus, São Paulo, SP, Brazil); $22 \mathrm{G}$ with apical opening (Ultradent Products, South Jordan, UT, USA); 30 with side opening (Optimus); and $30 \mathrm{G}$ with apical opening (NaviTip; Ultradent Products, South Jordan, UT, USA). All teeth $(n=12)$ were submitted to those 4 irrigation techniques at each stage. Thus, the same tooth was irrigated and evaluated 12 times ( 3 diameters and 4 types of needle). Depth of needle placement was determined by introducing the needles until resistance was felt and then reducing $1 \mathrm{~mm}$ to prevent obliteration of the root canal lumen. Irrigation was carried out with $2 \mathrm{~mL}$ distilled water in $5 \mathrm{~mL}$ plastic syringes, at a speed of $5 \mathrm{~mL} / \mathrm{min}$, controlled by a chronometer. A gentle back-and-forth motion with $2 \mathrm{~mm}$ amplitude was applied to the needle during irrigation. The irrigation solution was then aspirated with a suction cannula (BD, São Paulo, SP, Brazil) placed in the pulp chamber.

Before and after the irrigation procedure, each specimen was held with impression material (Zetaplus; Zhermach, Badia Polesine, RO, Italy) onto a positioning apparatus and radiographed buccal-lingually and mesial-distally using a Kodak RVG 6000 digital system (Eastman Kodak Company, Rochester, NY, USA) and a Spectro II X-ray unit (DabiAtlante, Ribeirão Preto, SP, Brazil) set for an exposure of 0.5 s. Images were captured by a charge coupled device (CCD) connected to a computer by an optic fiber cable. Those 12 teeth were radiographed repeatedly to assess the 4 types of needle in the three different stages of canal widening. Following that, the pre- and post-irrigation digital images were subjected to subtraction using the Adobe Photoshop CS4 program (Adobe Systems Inc., San Jose, CA) (Fig. 1) and then transferred to the Image Tool 3.0 software. The root canals were divided into thirds and only the apical portion was evaluated. Pre-irrigation areas (completely filled with contrast medium) and subtracted areas (region cleaned by irrigation) were outlined by a trained and blinded operator.

Areas were measured in $\mathrm{mm}^{2}$. The ratios between the pre- and post-irrigation areas for each specimen were calculated and expressed as percentages of apical third cleaning for each irrigation mode (different gauges and needle designs, and size of root canal widening). The results were obtained using an average of the buccal-lingual and mesial-distal measurements.

Comparison between percentages obtained for each mode was performed by one-way ANOVA and Tukey's posthoc tests. The significance level was set at 0.05 .

\section{Results}

Comparison among the 4 experimental groups showed that the $30 \mathrm{G}$ needles with side opening and apical opening presented better ability to remove contrast medium from the apical third after endodontic irrigation at all stages of root canal widening (Table 1).

Comparison of needle performance in the different diameters showed that all groups, except for the $22 \mathrm{G}$ with apical opening, performed better in root canals widened up to a size $40 \mathrm{~K}$-file. However, these differences were not statistically significant $(p>0.05)$.

\section{Discussion}

Different irrigation needle gauges and designs may affect the efficacy of endodontic irrigation in cleaning the
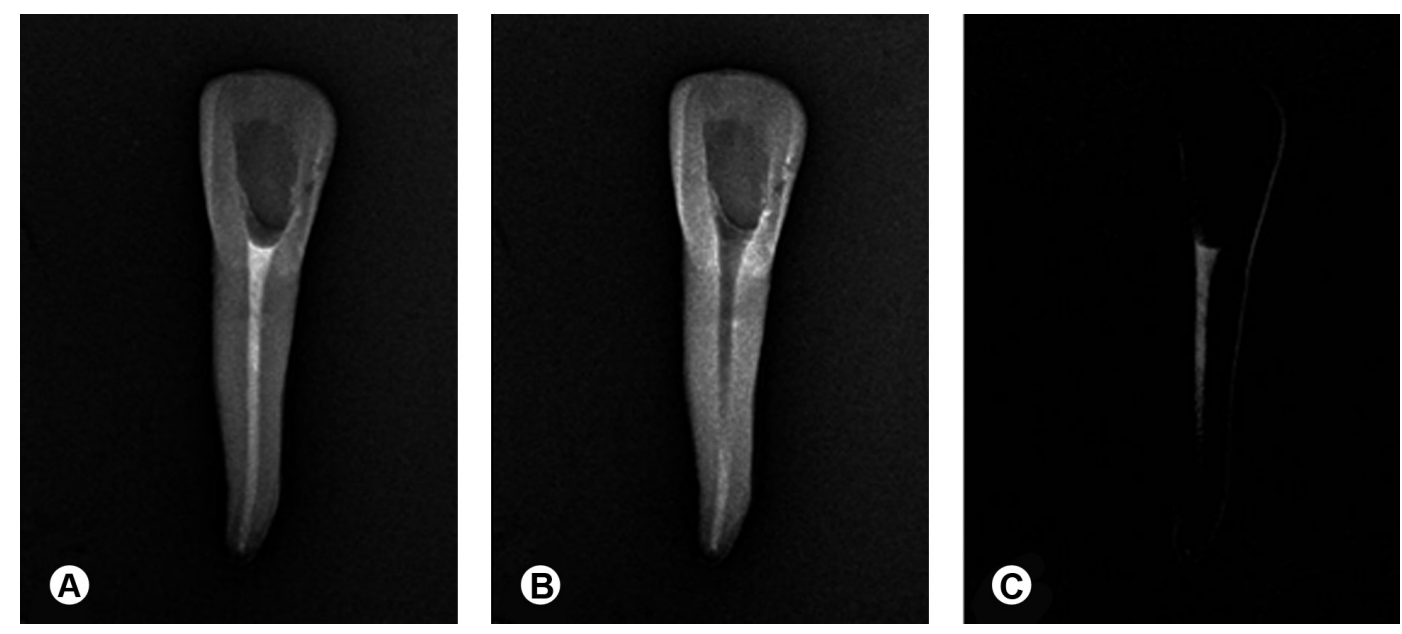

Figure 1. Subtraction process. A: Area filled with contrast medium. B: Area cleaned by irrigation. C: Resulting image after digital subtraction. 
root canal. The obtained results demonstrated that $30 \mathrm{G}$ needles, regardless of tip design, were more efficacious in cleaning the apical portion with all diameters of root canal widening. Abou-Rass and Piccinino (7) reported similar results from a study in which radiopaque medium was mixed with dentin shavings and injected in root canals of extracted mandibular molars. Using thermal image analysis, Hsieh et al. (8) demonstrated that the flow of root canal irrigation could be adversely affected by the use of large diameter needles.

The root canals were instrumented up to sizes 20,30 or $40 \mathrm{~K}$-files, obtaining apical preparation with diameters of $0.2,0.3$ or $0.4 \mathrm{~mm}$, respectively The obtained results show that $30 \mathrm{G}$ needles ( $0.3 \mathrm{~mm}$ external diameter) can reach or get close to the working length, improving efficacy (3). On the other hand, $23 \mathrm{G}$ needles ( $0.6 \mathrm{~mm}$ external diameter) cannot penetrate deeply into the root canal and therefore may not allow adequate cleaning.

Cleaning the apical third of root canals with conventional needle irrigation is a challenge. Studies using optical and scanning electron microscopes show the difficulty to remove debris in this area $(15,16)$. New irrigant agitation techniques and devices have been developed over the years in order to improve apical cleaning, such as EndoVac and RinsEndo systems (17). These novel devices are based on pressure-suction technology. Vivan et al. (18) did not find significant difference in the cleaning capacity of RinsEndo and conventional irrigation with syringe and $30 \mathrm{G}$ needles. Also, passive ultrasonic irrigation has been recommended to improve irrigant penetration into the root canal system (19). The main drawback of these new systems is their high cost.

Extrusion of irrigating solution through the periapical tissues has been described (20). For this reason, irrigation needles with a side opening have been developed to minimize the risk of extrusion and tissue damage $(21,22)$. In this study, two different needle designs (side or apical opening) resulted in similar percentages of apical cleaning for all root canal widening. Conversely, Kahn et al. (21) reported that side-vented closed-end needles were more

Table 1. Means (\%) and standard deviations of apical cleaning obtained with the different needles for each diameter of root canal widening

\begin{tabular}{lccc}
\hline Group $(\mathrm{n}=12)$ & Size $20 \mathrm{~K}$-file & Size $30 \mathrm{~K}$-file & Size 40 K-file \\
\hline $23 \mathrm{G} \mathrm{w} / \mathrm{SO}$ & $42.97(27.70) \mathrm{A}, \mathrm{ab}$ & $35.60(21.52) \mathrm{A}, \mathrm{a}$ & $55.38(22.38) \mathrm{A}, \mathrm{ab}$ \\
$22 \mathrm{G} \mathrm{w} / \mathrm{AO}$ & $36.82(18.93) \mathrm{A}, \mathrm{b}$ & $41.29(19.55) \mathrm{A}, \mathrm{a}$ & $40.54(21.83) \mathrm{A}, \mathrm{b}$ \\
$30 \mathrm{G} \mathrm{w} / \mathrm{SO}$ & $61.59(17.74) \mathrm{A}, \mathrm{a}$ & $62.43(19.55) \mathrm{A}, \mathrm{b}$ & $70.91(15.99) \mathrm{A}, \mathrm{a}$ \\
$30 \mathrm{G} \mathrm{w} / \mathrm{AO}$ & $62.04(17.27) \mathrm{A}, \mathrm{a}$ & $68.34(12.22) \mathrm{A}, \mathrm{b}$ & $74.80(13.39) \mathrm{A}, \mathrm{a}$ \\
\hline
\end{tabular}

SO: side opening. A0: apical opening. Same uppercase letters in the same row and lowercase letters in the same column indicate statistically similar means $(\mathrm{p} \geq 0.05)$. efficacious than conventional needles in clearing red food dye from root canals. It is important to point out that these authors employed a different methodology, using red food dye in clear plastic blocks and artificial root canals.

According to Usman et al. (4), the instrument size can influence the efficacy of root canal debridement. In this study, the needles performed better in root canals widened with a size $40 \mathrm{~K}$-file, except for $\mathrm{G} 2$, but the difference was not significant. This lack of statistical significance could be related to the coronal preflaring performed previously in all teeth. Albrecht et al. (23), using nickel-titanium rotary instruments, reported that debris was more effectively removed when the apical preparation size was larger (size 40 compared with size 20). However, when an instrument with larger taper was used, there was no difference between the two preparation sizes.

The irrigation speed adopted, $5 \mathrm{~mL} / \mathrm{min}$, was based on the study of Boutsioukis et al. (24). These authors evaluated the flow of solution using transductors to compare irrigation performed with $25 \mathrm{G}, 27 \mathrm{G}$ and $30 \mathrm{G}$ needles, and concluded that needles with smaller diameter require increased force. Excessive speed and force should be avoided during irrigation, due to the risk of apical extrusion.

Recent studies employing a computational fluid dynamics model have shown that the tip design of the needle affects the irrigant flow pattern, speed and the resulting apical pressure $(24,25)$. This methodology demonstrated that needles with side or beveled openings did not present advantages for irrigation of the apical portion of the root when compared to conventional needles with apical opening, agreeing with the observations in the present study. However, these modified needle tips reduced the pressure generated at the apical foramen, which may minimize the risk of extrusion of the irrigant into the periapical tissues. Further studies focusing on the extrusion of irrigants should be performed to define the ideal irrigation needle tip design that incorporates efficacy and safety during endodontic irrigation.

Based on the results, it may be concluded that narrow needles (30G) are more efficacious in cleaning the apical portion of the root canal in mandibular incisors. Large needles (22G and 23G) are not adequate for root canals enlarged up to size 40 hand files. Needles presenting side or apical openings did not differ in their performances. The greater the widening during root canal preparation, the greater the percentages of apical cleaning despite the lack of statistical significance. 


\section{Resumo}

Este estudo teve como objetivo avaliar a influência do diâmetro e design da agulha de irrigação e do diâmetro do canal radicular na eficácia de limpeza apical. Doze incisivos mandibulares humanos foram utilizados. Em diferentes fases de alargamento do canal radicular (limas tipo K \#20, 30 e 40), os canais foram preenchidos com meio de contraste radiopaco. Quatro agulhas diferentes foram avaliadas: $23 \mathrm{G}$ com abertura lateral, $22 \mathrm{G}$ com abertura apical, $30 \mathrm{G}$ com abertura lateral e $30 \mathrm{G}$ com abertura apical. A irrigação foi realizada com $2 \mathrm{~mL}$ de água destilada. 0 mesmo dente foi radiografado por um sistema digital, repetidas vezes, para avaliar os quatro diferentes tipos de agulha nas três fases de alargamento do canal. As imagens pré-irrigação (preenchidas por contraste) e pós-irrigação (com contraste restante) foram submetidas à subtração digital por meio do programa Adobe Photoshop CS4. As áreas pré-irrigação (preenchidas por contraste) e subtraidas (limpas pelo irrigante) foram demarcadas por um operador treinado e cego em relação aos grupos experimentais, usando o programa Image Tool 3.0. A proporção dessas duas medidas foi calculada para expressar a porcentagem de limpeza apical em cada estágio de dilatação $(20,30$ e 40$)$ com cada agulha. Os dados obtidos foram submetidos aos testes ANOVA a um critério e Tukey com nivel de significância de 5\%. As agulhas $30 \mathrm{G}$ com abertura lateral e apical promoveram melhor limpeza apical em todas as fases de ampliação do canal radicular $(p<0,05)$. Em conclusão, as agulhas de menor diâmetro foram mais eficazes na limpeza do terço apical dos canais radiculares, independentemente do seu design.

\section{References}

1. Lin LM, Skribner JE, Gaengler P. Factors associated with endodontic treatment failures. J Endod 1992;18:625-627.

2. Berber VB, Gomes BPFA, Sena NT, Vianna ME, Ferraz CCR, Zaia AA, et al.. Efficacy of various concentrations of $\mathrm{NaOCl}$ and instrumentation techniques in reducing Enterococcus faecalis within root canal and dentinal tubules. Int Endod J 2006;39:10-17.

3. Sedgley CM, Nagel AC, Hall D, Applegate B. Influence of irrigant needle depth in removing bioluminescent bacteria inoculated into instrumented root canals using real-time imaging in vitro. Int Endod J 2005;38:97-104.

4. Usman N, Baumgartner JC, Marshall JG. Influence of instrument size on root canal debridement. J Endod 2004;30:110-112.

5. Nguy D, Sedgley $C$. The influence of canal curvature on the mechanical efficacy of root canal irrigation in vitro using real-time imaging of bioluminescent bacteria. J Endod 2006;32:1077-1080.

6. Gulabilava K, Patel B, Evans G, Ng YL. Effects of the mechanical and chemical procedures on root canal surfaces. Endod Top 2005;10:103122.

7. Abou-Rass M, Piccinino MV. The effectiveness of four clinical irrigation methods on the removal of root canal debris. Oral Surg Oral Med Oral Pathol 1982;54:323-328.

8. Hsieh YD, Gau CH, Kung Wu SF, Shen EC, Hsu PW, Fu E. Dynamic recording of irrigating fluid distribution in root canals using thermal image analysis. Int Endod J 2007;40:11-17.

9. Boutsioukis C, Lambrianidis T, Vasiliadis L. Clinical relevance of standardization of endodontic irrigation needle dimensions according to the ISO 9626:1991/AMD 1:2001 specification. Int Endod J 2007;40:700-706.

10. Ram Z. Effectiveness of root canal irrigation. Oral Surg Oral Med Oral Pathol 1977;44:306-312.

11. Carvalho FB, Gonçalves M, Tanomaru-Filho M. Evaluation of chronic periapical lesions by digital subtraction radiography by using Adobe Photoshop CS: a technical report. J Endod 2007;33:493-497.

12. Bronnec F, Bouillaguet $S$, Machtou P. Ex vivo assessment of irrigant penetration and renewal during the cleaning and shaping of root canals: a digital subtraction radiographic study. Int Endod J 2010;43:275-282.

13. Almeida $\mathrm{SM}$, Oliveira $\mathrm{AEF}$, Ferreira RI, Bóscolo FN. Image quality in digital radiographic systems. Braz Dent J 2003;14:136-141.

14. Pace SRB, Habitante SM. Comparative analysis of the visualization of small files using digital and conventional radiography. J Appl Oral Sci 2005;13:20-23.

15. Baratto-Filho F, Carvalho Jr JR, Fariniuk LF, Sousa-Neto MD, Pécora JD, Cruz-Filho AM. Morphometric analysis of the effectiveness of different concentrations of sodium hypochlorite associated with rotary instrumentation for root canal cleaning. Braz Dent J 2004;15:36-40.

16. Ribeiro EM, Silva-Sousa YT, Souza-Gabriel AE, Sousa-Neto MD, Lorencetti KT, Silva SR. Debris and smear removal in flattened root canals after use of different irrigant agitation protocols. Microsc Res Tech 2012;75:781-790.

17. Gu LS, Kim JR, Ling J, Choi KK, Pashley DH, Tay FR. Review of contemporary irrigant agitation techniques and devices. J Endod 2009;35:791-804.

18. Vivan RR, Bortolo MV, Duarte MAH, Moraes IG, Tanomaru-Filho M, Bramante CM. Scanning electron microscopy analysis of RinsEndo system and conventional irrigation for debris removal. Braz Dent J 2010;21:305-309.

19. Munoz HR, Camacho-Cuadra K. In vivo efficacy of three different endodontic irrigation systems for irrigant delivery to working length of mesial canals of mandibular molars. J Endod 2012;38:445-448.

20. Zairi A, Lambrianidis T. Accidental extrusion of sodium hypochlorite into the maxillary sinus. Quintessence Int 2008;39:745-748.

21. Kahn FH, Rosenberg PA, Gliksberg J. An in vitro evaluation of the irrigating characteristics of ultrasonic and subsonic handpieces and irrigating needles and probes. J Endod 1995;21:277-280.

22. Vinothkumar TS, Kavitha S, Lakshminarayanan L, Gomathi NS, Kumar $\mathrm{V}$. Influence of irrigating needle-tip designs in removing bacteria inoculated into instrumented root canals measured using single-tube luminometer. J Endod 2007;33:746-748.

23. Albrecht $\sqcup$, Baumgartner JC, Marshal JG. Evaluation of apical debris removal using various sizes and tapers of ProFile GT files. J Endod 2004;30:425-428.

24. Boutsioukis C, Verhaagen B, Versluis M, Kastrinakis E, Wesselink PR, Van der Sluis LWM. Evaluation of irrigant flow in the root canal using different needle types by an unsteady computational fluid dynamics model. J Endod 2010;36:875-879.

25. Shen Y, Gao Y, Qian W, Ruse ND, Zhou X, Wu H, et al.. Three-dimensional numeric simulation of root canal irrigant flow with different irrigation needles. J Endod 2010;36:884-889.

Received December 19, 2012 Accepted January 30, 2013 